\title{
Fertility Among Orphans in Rural Malawi: Challenging Common Assumptions About Risk and Mechanisms
}

By Rachel Kidman and Philip Anglewicz

Rachel Kidman is assistant professor, Program in Public Health and Department of Preventive Medicine, Stony Brook University, Stony Brook, NY, USA. Philip Anglewicz is assistant professor,

Department of Global Health Systems and Development, School of Public Health and Tropical Medicine, Tulane University, New Orleans, LA, USA.

\begin{abstract}
CONTEXT: Although a substantial literature suggests that orphans suffer disadvantage relative to nonorphaned peers, the nature of this disadvantage and the mechanisms driving it are poorly understood. Some evidence suggests that orphans experience elevated fertility, perhaps because structural disadvantage leads them to engage in sexual risk-taking. An alternative explanation is that orphans intentionally become pregnant to achieve a sense of normality, acceptance and love.
\end{abstract}

METHODS: Data from the 2006 wave of the Malawi Longitudinal Study of Families and Health on 1,033 young adults aged 15-25 were used to examine the relationship of maternal and paternal orphanhood with sexual risk indicators and desired and actual fertility. Regression analyses were used to adjust for covariates, including social and demographic characteristics and elapsed time since parental death.

RESULTS: Twenty-six percent of respondents had lost their father and 15\% their mother. Orphanhood was not associated with sexual risk-taking. However, respondents whose mother had died in the past five years desired more children than did those whose mother was still alive (risk differences, 0.52 among women and 0.97 among men). Actual fertility was elevated among women whose father had died more than five years earlier (0.31) and among men whose mother had died in the past five years (1.06) or more than five years earlier (0.47).

CONCLUSION: The elevations in desired and actual fertility among orphans are consistent with the hypothesis that orphans intentionally become pregnant. Strategies that address personal desires for parenthood may need to be part of prevention programs aimed at orphaned youth.

International Perspectives on Sexual and Reproductive Health, 2014, 40(4):164-175, doi: 10.1363/4016414

In Sub-Saharan Africa, millions of youth have lost one or both parents to the HIV epidemic. A parental death can have a profound impact on children and young adults, and practitioners and researchers alike have emphasized the adverse consequences of orphanhood. Indeed, a substantial body of literature has identified disparities in health, education and economic outcomes between orphaned and nonorphaned children, ${ }^{1}$ and concern is growing about the reproductive health of orphaned adolescents and youth. One area of concern is fertility, as early childbearing is associated with substantial mortality for both mothers and infants in developing countries. ${ }^{2}$

The relationship between orphanhood and pregnancy has not been decisively established. In the past decade, six studies have assessed this relationship in Sub-Saharan Africa, and four demonstrated higher rates of pregnancy among orphans than among nonorphans. ${ }^{3-6}$ However, the geographic scope of these studies was limited to Zimbabwe and South Africa, and the relationship between orphanhood and pregnancy may be different in other settings. In addition, these findings are contradicted by those from two more recent studies, which also included data from Zimbabwe and South Africa. ${ }^{7.8}$ In particular, Palermo and Peterman examined this issue using data from 10 countries in Sub-Saharan Africa, and found differences in only three. ${ }^{7}$ Extending analyses to other countries could yield important information about how orphanhood affects fertility in different social contexts.

\section{Potential Mechanisms}

When differences in fertility by orphan status do emerge in the literature, they are implicitly ascribed to increased structural vulnerability (e.g., poverty) and related sexual risk-taking among orphans. However, as we shall see, the exact mechanisms through which orphanhood may affect risk behavior have not been clearly established, and may differ across settings. This is a critical oversight, as the success of programs to identify and assist at-risk youth likely hinges on a clear understanding of the mechanisms.

-Structural vulnerability and sexual risk. According to this pathway, the adverse impacts of orphanhood, such as impoverishment and educational curtailment, reduce sexual power. As a result, orphans may be more easily exploited or coerced into having high-risk sex than nonorphans, and unwanted pregnancies may result. For example, Gregson and colleagues noted that female orphans had a lower likelihood than nonorphans of completing secondary school, which in turn was associated with adverse reproductive outcomes. They concluded: "High proportions of HIV infections, STIs and pregnancies among teenage girls in east- 
ern Zimbabwe can be attributed to maternal orphanhood and parental HIV. Many of these could be averted through further female secondary school education." $3($ p.785)

To examine the supporting evidence, we have broken the structural vulnerability pathway into three components: Orphans experience greater socioeconomic disadvantage; orphans engage in higher levels of sexual risk behavior; and socioeconomic disadvantage drives sexual risk-taking among orphans. We find the evidence for all three to be inconclusive.

An extensive body of research has examined economic insecurity and educational disadvantage among orphans, ${ }^{9}$ and evidence has been mixed. Longitudinal studies in South Africa and Kenya have documented lower rates of school enrollment among orphans than among nonorphans, ${ }^{10,11}$ but studies in Malawi, Tanzania and Burkina Faso have found no disadvantage among orphans. ${ }^{12,13}$ Where educational disparities do appear, they are largely associated with maternal orphanhood. ${ }^{9}$ The picture that emerges concerning economic disadvantage is equally varied, with regard to both country context and type of orphan. ${ }^{14,15}$ Unlike schooling, poverty is more common among paternal than maternal orphans. ${ }^{15}$ Taken together, the evidence suggests that disparities between orphans and nonorphans in human capital accumulation are not always present, and that they depend on the context, orphan type and specific outcome under study.

A similar pattern emerges for sexual risk. While research has often found earlier age of sexual debut among female orphans than among nonorphans, ${ }^{4,5,7}$ comparisons for other measures of sexual risk have produced conflicting results. Some studies have documented elevated levels of sexual risk indicators-including multiple partnerships, transactional sex and forced sex-among female orphans, 5,6,16,17 but null findings have been widely reported among both female 8,18 and male orphans. ${ }^{3,5,8,19}$ Thus, the wealth of studies on the impact of orphanhood on sexual risk behavior have not yielded consistent results.

Finally, a number of studies have tested the link between structural vulnerability and sexual risk-taking among orphans, once again with mixed results. While two studies reported that poverty mediates the likelihood of high-risk sex among orphans, ${ }^{16,20}$ many more have found that the relationship between orphanhood and risky sex persists after adjustment for socioeconomic factors., ${ }^{5,21-23}$

- Consequences of fertility preference. The frequent focus on sexual risk-taking and associated unintended pregnancies in orphanhood research obscures the fact that three out of four adolescent births worldwide are planned. ${ }^{24}$ In SubSaharan Africa, parenthood plays an important role in life aspirations and social standing, ${ }^{25-27}$ for men, fatherhood affirms masculinity. ${ }^{28,29}$ In this context, early births are socially acceptable and even encouraged. Thus, in times of bereavement and uncertainty, orphans may see parenthood as a path to normalcy, social acceptance and a more positive future. Furthermore, orphans may seek to accelerate this process if they perceive their future HIV risk to be high. In this scenario, pregnancy-or more specifically, the desire for it-may drive sexual behavior, rather than be an unanticipated and unwanted outcome. We explore this alternative pathway in more detail below.

Evidence strongly suggests that pregnancy intentions are highly related to contraceptive use and pregnancy outcomes among adolescents. ${ }^{30,31}$ There is also a robust literature, though mostly from developed countries, that shows that pregnancy intentions are highest among the most disadvantaged individuals. ${ }^{32}$ Specifically, low levels of perceived family support ${ }^{33}$ and high levels of family stress $^{34}$ are positively associated with pregnancy desire among American adolescents. Under such circumstances, early childbearing provides an opportunity to feel more loved, create family stability and reduce uncertainty. ${ }^{35,36}$ However, few studies have examined the psychosocial determinants of fertility intention among youth, ${ }^{33,37}$ and we know of none that have focused on Sub-Saharan Africa.

Pregnancy intentions are not static, but rather are dynamic. ${ }^{38-40}$ Longitudinal research in Africa has demonstrated temporal changes in preferences regarding the number and timing of births. ${ }^{41-43}$ In a study in Ghana, $20 \%$ of women changed their fertility desires in the nine months between survey waves. ${ }^{42} \mathrm{~A}$ two-year study of Malawian young adults aged 15-25 found even greater instability: Approximately a quarter altered their preference in any given three-month period, and only a third maintained a consistent preference across all eight survey waves. ${ }^{43}$ These findings are consistent with research from developed countries that suggests that fertility preferences are most flexible at the beginning of the reproductive life cycle. ${ }^{38}$

Importantly, changes in fertility preference are not random: They are a response to changing circumstances and key life events (e.g., marriage, divorce and impoverishment). ${ }^{38-40,42,43}$ As events unfold, individuals reassess the pros and cons of childbearing and adjust their preferences accordingly. ${ }^{39}$ Those who reap benefit from childbearing may adjust their fertility preference upward. ${ }^{39}$ In the Malawi study, fertility preference increased in the year after the death of a child. ${ }^{43}$ Less is known about whether the influence of key life events extends over many years; research in this area has been limited to developed countries and provides only weak evidence for the impact of early life experiences on fertility preferences. ${ }^{39}$

We suggest that orphanhood is a traumatic life event and that this experience influences fertility preferences. The death of a parent brings numerous psychological and social challenges. In addition to grief and bereavement, many orphans experience depression and anxiety. ${ }^{44,45}$ These challenges may be accompanied by social instability, including household disintegration, migration and separation from siblings. ${ }^{46-48}$ When AIDS is the suspected cause of death, orphans may experience secondary stigma, ${ }^{45,49}$ exacerbating their feelings of isolation.

In times of bereavement and family instability, orphans may see special benefits to childbearing. Children can be a source of love, hopefulness and meaning, which may take 
TABLE 1. Selected characteristics of young adults aged 15-25, by sex, Malawi Longitudinal Study of Families and Health, 2006

\begin{tabular}{|c|c|c|c|}
\hline Characteristic & $\begin{array}{l}\text { All } \\
(\mathrm{N}=1,069)\end{array}$ & $\begin{array}{l}\text { Women } \\
(\mathrm{N}=587)\end{array}$ & $\begin{array}{l}\text { Men } \\
(\mathrm{N}=482)\end{array}$ \\
\hline \multicolumn{4}{|l|}{ SOCIAL AND DEMOGRAPHIC } \\
\hline Mean age & 20.9 & 20.7 & 21.0 \\
\hline \multicolumn{4}{|l|}{ Mean normalized wealth } \\
\hline \multicolumn{4}{|l|}{ Marital status } \\
\hline Married & 59.3 & 73.7 & 41.2 \\
\hline Never married & 36.0 & 19.1 & 57.3 \\
\hline Divorced/separated/widowed & 4.7 & 7.2 & 1.5 \\
\hline \multicolumn{4}{|l|}{ Region } \\
\hline Central & 31.4 & 34.6 & 27.3 \\
\hline South & 35.3 & 33.6 & 37.5 \\
\hline North & 33.3 & 31.8 & 35.2 \\
\hline \multicolumn{4}{|l|}{ Education } \\
\hline None & 12.1 & 14.7 & 9.8 \\
\hline Primary & 65.8 & 69.3 & 61.2 \\
\hline$\geq$ secondary & 22.1 & 17.0 & 29.0 \\
\hline \multicolumn{4}{|l|}{ Mother's status } \\
\hline Alive & 84.7 & 83.5 & 86.2 \\
\hline Died in past $5 \mathrm{yrs}$. & 4.2 & 5.3 & 2.8 \\
\hline Died >5 yrs.ago & 11.1 & 11.2 & 11.0 \\
\hline \multicolumn{4}{|l|}{ Father's status } \\
\hline Alive & 73.6 & 73.3 & 74.0 \\
\hline Died in past $5 \mathrm{yrs}$. & 7.5 & 7.2 & 7.9 \\
\hline Died > 5 yrs.ago & 18.9 & 19.5 & 18.1 \\
\hline \multicolumn{4}{|l|}{ RISK INDICATORS } \\
\hline Mean no. of partners & 2.5 & 1.8 & 3.4 \\
\hline Ever exchanged sex for money & 25.0 & 18.9 & 29.4 \\
\hline Has had extramarital partner & 9.8 & 3.4 & 18.3 \\
\hline HIV-positive & 4.2 & 5.7 & 2.4 \\
\hline Worried about HIV & 14.8 & 15.6 & 13.8 \\
\hline \multicolumn{4}{|l|}{ FERTILITY OUTCOMES } \\
\hline Mean no. of children desired & 3.7 & 3.7 & 3.6 \\
\hline Mean no. of children ever born & 1.2 & 1.7 & 0.7 \\
\hline Mean no. of living children & 1.2 & 1.5 & 0.7 \\
\hline
\end{tabular}

Notes: All values are percentages unless otherwise indicated. Sample sizes vary slightly.Percentages may not total 100.0 because of rounding.

on extra importance when these are missing. ${ }^{50}$ Some empirical evidence supports this possibility. In a qualitative study of disadvantaged U.S adolescents, most of whom were not living with their parents, some participants said they wanted a baby to fulfill a need for love and to avoid loneliness. ${ }^{51}$ Similarly, girls from unstable families in Nicaragua reported seeking love and affection through alternative family formation. ${ }^{52}$ Evidence from Africa is limited, but in a qualitative study conducted in South Africa, people living with HIV reported that having children brought hope, happiness and a sense of normality. ${ }^{50}$

Orphans may also desire children to solidify relationships and increase the chances of marriage. Not only do many adolescent pregnancies precede marriage, but a Kenyan study showed that premarital pregnancies were associated with a 13-fold increase in the likelihood of a relationship transitioning toward marriage. ${ }^{53}$ We know of only one study that examined the link between AIDS orphans' psychosocial state and entry into intimate relationships, and none that examined fertility specifically. However, in qualitative work by Majola, ${ }^{54}$ orphaned girls described a lack of parental love as motivating their relationship choices and sexual behavior.

Finally, orphans whose parents died of AIDS may grapple with uncertainty about their own HIV status. Childbearing may take on greater urgency for those who suspect they are or will become infected: They may want to have children before they contract HIV or develop AIDS. Critically, studies in Mozambique and Malawi have shown that individuals who perceive a high likelihood of being or becoming HIV-positive are more likely than others to accelerate childbearing. ${ }^{55,56}$ Moreover, research on people living with HIV suggests that childbearing may be viewed as a way of achieving normalcy and hope for the future..$^{50,57,58}$ If parental mortality influences orphans' perceptions of HIV risk, childbearing may take on comparable importance and urgency in this population.

Taken together, the evidence cited above suggests that fertility preferences may change in response to key life events, ${ }^{43}$ and that orphanhood may be a particularly salient experience in this regard. We suggest that orphans are more likely than other youth to view childbearing as a pathway to a better future and greater social acceptance, and that this may explain excess pregnancy rates. We are not aware of prior studies that have tested such a theory.

\section{Our Study}

Since neither the exact nature of orphan disadvantage nor the specific mechanisms that explain it are well understood, we used data from rural Malawi, a country in the grips of both extreme poverty and a generalized AIDS pandemic, to answer the following questions: Do orphaned youth experience greater structural disadvantage (via wealth and education) and engage in higher levels of sexual risk behavior than do nonorphans? And do orphaned youth report heightened fertility desires and childbearing compared with nonorphans?

To answer these questions, we used a rich data set that allowed for nuanced exploration of how orphanhood type, orphanhood duration and gender may influence any associations we observed. Previous research suggests that reproductive health outcomes vary substantially between maternal and paternal orphans. ${ }^{59}$ While the role of orphanhood duration is far less studied, evidence and theory suggest that it may be equally important in understanding the impact of losing one or both parents. ${ }^{6,19}$ Specifically, the recency of parental loss may drive an orphan's emotional state and, in turn, current fertility desires. Finally, all previous work on orphanhood and fertility has been restricted to women. We examined orphanhood among members of both sexes, recognizing that fertility is not solely a woman's issue. Moreover, we built gender-specific models to discern whether different mechanisms underlie risk for male and female orphans. By expanding the investigation to include fertility intentions, examining the salience of orphanhood duration and including males, this 
study opens the door to a more complete understanding of fertility among orphans.

\section{METHODS}

\section{Setting}

Our data come from Malawi, where 11\% of adults aged 15-49 were HIV-positive in 2010. ${ }^{60}$ In addition to having among the highest HIV prevalence in the world, Malawi is one of the poorest countries: It was ranked 170th of the 186 countries rated in the 2013 Human Development Index report. ${ }^{61}$ More than seven million youth younger than 18 are being raised in this environment, approximately $13 \%$ of whom have lost one or both parents. ${ }^{62}$ In 2004 , the proportion of Malawian youth younger than 18 who were orphans varied geographically in a pattern similar to that of HIV prevalence: The proportion was higher in urban areas (18\%) than in rural areas (14\%). ${ }^{63}$

Malawi shares several fertility-related characteristics with most other countries in Sub-Saharan Africa. The rate of union formation is high: Nearly all women marry by their mid-20s. ${ }^{64}$ Malawi also has relatively high fertility (the total fertility rate was 6.0 in $2004^{62}$ ), and most childbearing takes place within marriage. ${ }^{65}$ However, residents of Malawi marry at an earlier age than do those of most other countries in Sub-Saharan Africa: The mean age at first marriage is approximately 18 for women and 23 for men. ${ }^{63,64}$ Not surprisingly, then, age at first childbearing and age at sexual debut are also relatively young: In the 2004 Demographic and Health Survey, about half of women had given birth by age 18 , and the average age at sexual debut was 17.3 for women aged $20-49$ and 18.5 for men aged $20-54 .{ }^{63}$

\section{Data Source}

We used data from the Malawi Longitudinal Study of Families and Health (MLSFH).* This data set has several important features that enabled us to address our research questions, notably information on a variety of key variables-including orphan status, time since parental death, and actual and desired fertility-for both women and men. Designed as a couples survey, the MLSFH initially targeted a population-based representative sample of approximately 1,500 ever-married women and 1,000 of their husbands in three rural sites of Malawi. Following enumeration of households in the three designated sites in 1998, approximately 500 ever-married women aged 15-49 and their spouses were randomly selected to be interviewed at each site. Follow-up interviews were conducted with all participants in 2004, 2006, 2008 and 2010. In addition, in 2004, the MLSFH added a new sample of approximately 1,500 young adults aged 15-24 (both ever- and nevermarried) and offered HIV testing to all respondents. The spouses of respondents who married between waves were also interviewed. Acceptance rates for testing were more than 90\% in 2004 and 2006; all tested respondents were given the opportunity to receive their results. The MLSFH sample is generally comparable to the rural sample of Ma-
TABLE 2. Risk differences and odds ratios (with standard errors) from multivariate regression analyses examining associations of orphanhood status and selected covariates with wealth and education among Malawian young adults aged 15-25, by sex

Characteristic

\begin{tabular}{lllll} 
& Women & Men & Women & Men \\
\cline { 2 - 5 } & & & & \\
\hline $\begin{array}{l}\text { ORPHANHOOD } \\
\text { Mother's status } \\
\text { Alive (ref) }\end{array}$ & 0.00 & 0.00 & 1.00 & 1.00 \\
$\begin{array}{l}\text { Died in past 5 yrs. } \\
\text { Died >5 yrs.ago }\end{array}$ & $-0.36(0.35)$ & $-0.56(0.50)$ & $0.73(0.41)$ & $2.35(0.59)$ \\
& $-0.61(0.25)^{*}$ & $0.66(0.26)^{*}$ & $0.72(0.30)$ & $0.57(0.34) \dagger$ \\
Father's status & & & & \\
Alive (ref) & 0.00 & 0.00 & 1.00 & 1.00 \\
Died in past 5 yrs. & $0.09(0.31)$ & $-0.11(0.29)$ & $0.94(0.37)$ & $1.34(0.37)$ \\
Died >5 yrs.ago & $-0.17(0.20)$ & $-0.49(0.22)^{*}$ & $0.99(0.24)$ & $0.80(0.28)$ \\
COVARIATES & & & & \\
Age & $-0.09(0.03)^{* * *}$ & $-0.08(0.03)^{*}$ & $0.88(0.03)^{* *}$ & $1.05(0.04)$ \\
Region & & & & \\
Central (ref) & 0.00 & 0.00 & 1.00 & 1.00 \\
South & $-0.47(0.19)^{*}$ & $-0.08(0.20)$ & $0.72(0.23)$ & $0.76(0.26)$ \\
North & $1.38(0.19)^{* * *}$ & $1.41(0.20)^{* * *}$ & $7.21(0.26)^{* * *}$ & $5.17(0.26)^{* * *}$ \\
& & & &
\end{tabular}

${ }^{*} \mathrm{p} \leq .05 .{ }^{* *} \mathrm{p} \leq .01 .{ }^{* * *} \mathrm{p} \leq .001 .+\mathrm{p} \leq .10 . \neq$ Results reported as risk differences. Results reported as odds ratios. Notes: Regressions used in these analyses were ordinary least squares (wealth) and ordered logistic (education). ref=reference category.

lawi Demographic and Health Surveys. ${ }^{66,67}$ Descriptions of the MLSFH data and sampling are presented in detail elsewhere. ${ }^{66-68}$ The MLSFH study was approved by the Institutional Review Board of the University of Pennsylvania and by the Malawi National Health Sciences Research Committee.

We primarily used data from the 2006 wave of the MLSFH, as these data capture features essential for our analyses. The additions to the original sample increased the size of the target sample to approximately 5,000 respondents, of whom 3,431 (69\%) were successfully interviewed in 2006. For young adults aged 15-25 (the age-group relevant to our study), information on the variables of interest were available for 1,069 respondents (587 women and 482 men). For selected analyses, we also drew on data from the 2010 survey wave; 374 women and 288 men aged 15-25 in 2006 were also interviewed in 2010.

\section{Measures}

The 2006 MLSFH collected information on both parents of all respondents, including whether the parents had died and, if so, when. Because the socioeconomic and emotional impact of losing a parent may differ according to the sex of the parent, we created two trichotomous orphanhood variables-one for each parent-to indicate whether the parent was still alive, had died within the last five years (20012006) or had died more than five years earlier (prior to 2001). We distinguished between recent and nonrecent deaths because the former may have a more pronounced impact on current fertility desires than the latter.

*Between 1998 and 2004, the MLSFH was known as the Malawi Diffusion and Ideational Change Project. 
TABLE 3. Risk differences and odds ratios (with standard errors) from multivariate regressions examining associations of orphanhood status and selected covariates with sexual risk indicators among Malawian women aged 15-25

\begin{tabular}{|c|c|c|c|c|c|}
\hline Characteristic & $\begin{array}{l}\text { No.of } \\
\text { partnersł }\end{array}$ & $\begin{array}{l}\text { Ever } \\
\text { exchanged } \\
\text { sexfor } \\
\text { money§ }\end{array}$ & $\begin{array}{l}\text { Has had } \\
\text { extra- } \\
\text { marital } \\
\text { partner§ }\end{array}$ & $\begin{array}{l}\text { HIV- } \\
\text { positive§ }\end{array}$ & $\begin{array}{l}\text { Worried } \\
\text { about HIV§ }\end{array}$ \\
\hline
\end{tabular}

ORPHANHOOD STATUS

\section{Mother's status}

Alive (ref)

Died in past 5 yrs.

Died $>5$ yrs.ago

0.00

$0.10(0.15)$

1.00

$-0.10(0.12)$

$1.75(0.73)$

1.00

1.00

1.00

$0.84(0.27)$

$3.07(1.95) \dagger 1.94(2.24)$

$1.46(0.79)$

Father's status

Alive (ref)

Died in past 5 yrs.

\subsection{0}

$-0.08(0.15)$

1.00

$1.08(0.41)$

1.00

1.00

$0.04(0.09)$

$1.29(0.32)$

$1.08(0.54)$

$0.81(0.92)$

1.00

Died $>5$ yrs.ago

$0.03(0.01) \dagger$

$-0.02(0.02)$

$1.06(0.05)$

$1.06(0.09) \quad 1.47(0.19)^{* *}$

Age

$-0.02(0.02)-0.86(0.06)^{*}$

$0.84(0.14)$

$0.99(0.19)$

$0.90(0.06)$

$0.99(0.10) \quad 0.58(0.17)^{*}$

$0.99(0.05)$

$0.88(0.09)$

No. of living children

$-0.01(0.02)$

\section{Marital status}

Married (ref)

Never married

$-0.71(0.14)^{* *}$

1.00

1.00

1.00

1.00

Divorced/separated/

widowed

$0.26(0.12)^{*}$

$1.14(0.43)$

$0.42(0.44) \quad 2.53(1.77)$

$0.54(0.24)$

Region

Central (ref)

South

North

$\begin{array}{llll}0.00 & 1.00 & 1.00 & 1.00 \\ 0.05(0.08) & 2.28(0.53)^{* * *} & 0.86(0.38) & 2.60(1.60) \\ -0.32(0.10)^{* *} & 0.82(0.22) & 0.31(0.19)^{*} & 1.37(1.01)\end{array}$

1.00

$1.67(0.45) \dagger$

$0.31(0.13)^{* *}$

\section{Education}

None (ref)

Primary

$\geq$ secondary

$\begin{array}{lllll}0.00 & 1.00 & 1.00 & 1.00 & 1.00 \\ -0.12(0.09) & 1.30(0.38) & 0.89(0.46) & 0.33(0.21) \dagger & 1.15(0.37) \\ -0.08(0.15) & 1.70(0.71) & 1.81(1.47) & 0.53(0.53) & 1.50(0.82)\end{array}$

${ }^{*} \mathrm{p} \leq .05 .{ }^{* *} \mathrm{p} \leq .01 .{ }^{* * *} \mathrm{p} \leq .001 .+\mathrm{p} \leq .10$. $\neq$ Results reported as risk differences. §Results reported as odds ratios. Notes: Regressions used in these analyses were Poisson (number of partners) and logistic (remaining risk indicators). Sample size was 587 for all regressions except for that for HIV status, which had a sample size of 438 because some respondents did not want to be tested or could not be found by the testing team. ref=reference category. na=not applicable.

We included several measures of sexual risk in our analyses. Our selection of these variables was guided by the literature on sexual risk behavior for orphans and on sexual risk that may result from structural disadvantage. These measures were the overall number of sexual partners that the respondent had had, whether the respondent had engaged in transactional sex (exchanged sex for money) with any of his or her three most recent partners, whether the respondent had ever had an outside partner while in a marriage or stable relationship (for simplicity we refer to these partners as extramarital, regardless of whether the primary relationship was a formal marriage), HIV status and whether the respondent worried about becoming infected with HIV.

Respondents also reported their desired and actual fertility-the number of children they currently wanted and the number they had ever had. Fertility outcomes were assessed in both 2006 and 2010; we draw on both waves in our analyses. Finally, we included variables for a variety of background characteristics: an index measure of wealth, created using a principal components analysis of 12 household amenities; ${ }^{69}$ educational attainment (categorized as no education, some primary schooling, or at least some secondary schooling); age (continuous); region of residence (central, south or north); number of living children; and marital status (married, never married, or divorced, separated or widowed).

\section{Analytic Methods}

An important feature of our analysis is that we were able to establish the probable sequence in which most key outcomes of interest (including orphanhood) had occurred. Although our data were cross-sectional, we substantially reduced the likelihood that sexual risk behaviors and fertility desires preceded orphanhood by comparing retrospective reports of the timing of parental death with current behaviors in 2006. It is important to note, however, that we were unable to parse out whether orphanhood preceded actual fertility, particularly for respondents whose parents had died in the past five years. While this limitation may have biased the results toward the null, it would not have created a spurious correlation; while a parental death may influence fertility, it is unlikely that fertility preferences or childbearing contribute to parental death.

We conducted our analysis in three steps. First, we ran multivariate (logistic and ordinary least squares) regressions to examine whether orphans in Malawi experience structural disadvantage. The dependent variables in these regressions are wealth and education.

Second, we investigated whether sexual risk indicators differ between orphans and nonorphans. We again used multivariate regressions to identify these differences. The variables we examined were lifetime number of sex partners, having exchanged sex for money with a recent partner, having had another partner while married or in a steady relationship, HIV status and being worried about HIV infection. We examined HIV status only for women, since the number of HIV-positive men was too small for multivariate analysis. The type of regression differed according to the dependent variable; Poisson regression was used for the analysis of number of sex partners, and logistic regression was used for analyses of other risk indicators. Independent variables included in these analyses were education, wealth, age, region, orphanhood, marital status and number of living children.

Finally, we turned to fertility-related outcomes. To examine whether there were differences in these outcomes between orphans and nonorphans, we again ran multivariate regressions, using the same set of independent variables listed above. We began with a common proximate determinant of fertility, having ever been married. Next, we examined two fertility-related measures: desired total fertility and number of living children. Finally, we examined the relationship between orphanhood and longer-term fertility by running regressions in which orphanhood in 2006 was the key independent variable (the usual covariates were also included) and the total number of living children in 2010 was the dependent variable.

In addition to including separate indicators for maternal and paternal death, we stratified all analyses by the 
orphans' sex, which may modify the relationship between parental loss and reproductive choices (e.g., the consequences of a maternal death may be more pronounced for a female orphan).

\section{RESULTS}

Female and male respondents were similar in many regards. Both women and men were about 21 years old on average and were distributed almost evenly among the three regions (Table 1, page 166). Among both women and men, higher percentages had lost their father than had lost their mother (26-27\% vs. 14-17\%), which likely reflects that men in Malawi are typically older than their wives. The level of desired fertility was approximately the same across genders.

That said, values for several key variables differed between men and women. Men had higher educational attainment (29\% had attended secondary school, compared with $17 \%$ of women), while women were more likely than men to be married (and to be divorced, separated or widowed). On average, men reported having had 3.4 partners in their lifetime, while women reported having had 1.8. HIV prevalence was $6 \%$ among women and $2 \%$ among men. Finally, the mean number of living children was higher among men (1.7) than among women (0.7).

Our first regression examined whether orphans experience structural disadvantage (Table 2, page 167). We found some evidence that orphans in Malawi suffer from the same disadvantages as many of their counterparts elsewhere, although the differences were statistically significant only if the respondent's parent had died more than five years earlier. Female orphans whose mother had died more than five years earlier were less wealthy than nonorphans (risk difference, -0.61); similarly, male orphans whose father had died five or more years earlier were less wealthy than nonorphans (-0.49). While these results show a disadvantage for orphans in select instances, we note that men whose mother had died more than five years earlier actually had greater household wealth than their nonorphan peers.

Overall, orphans and nonorphans showed few differences in sexual behavior (Tables 3 and 4). Among women, orphans did not have elevated sexual risk on any of the outcomes, although there was a marginally significant association between having lost a mother in the past five years and having had another sexual partner while married or in a steady relationship (odds ratio, 3.1). Among men, those whose father had died more than five years earlier had had a greater number of sexual partners than had nonorphans (risk difference, 0.16). However, we found some evidence of reduced sexual risk among orphans: Women whose father had died more than five years earlier were less likely than nonorphans to be HIV positive, though this association was only marginally significant (0.1); and men whose father had died in the past five years were less likely than nonorphans to have had an extramarital partner (0.4). No associations were apparent between orphanhood and worry about HIV infection. \begin{tabular}{|l} 
TABLE 4. Risk differences and odds ratios (with standard errors) from multivariate \\
regressions examining associations of orphanhood status and selected covariates \\
with sexual risk indicators among Malawian men aged 15-25
\end{tabular}

\begin{tabular}{|c|c|c|c|c|}
\hline Characteristic & $\begin{array}{l}\text { No.of } \\
\text { partnersł }\end{array}$ & $\begin{array}{l}\text { Ever exchanged } \\
\text { sexfor } \\
\text { money§ }\end{array}$ & $\begin{array}{l}\text { Has had extra- } \\
\text { marital } \\
\text { partner§ }\end{array}$ & $\begin{array}{l}\text { Worried } \\
\text { about HIV§ }\end{array}$ \\
\hline \multicolumn{5}{|l|}{ ORPHANHOOD } \\
\hline \multicolumn{5}{|l|}{ Mother's status } \\
\hline Alive (ref) & 0.00 & 1.00 & 1.00 & 1.00 \\
\hline Died in past $5 \mathrm{yrs}$. & $-0.15(0.20)$ & $0.37(0.27)$ & $0.82(0.58)$ & $\mathrm{nr}$ \\
\hline Died > 5 yrs.ago & $0.15(0.09)$ & $1.03(0.35)$ & $1.01(0.37)$ & $0.69(0.34)$ \\
\hline \multicolumn{5}{|l|}{ Father's status } \\
\hline Alive (ref) & 0.00 & 1.00 & 1.00 & 1.00 \\
\hline Died in past $5 \mathrm{yrs}$. & $0.01(0.10)$ & $1.32(0.49)$ & $0.36(0.18)^{*}$ & $0.84(0.45)$ \\
\hline Died >5 yrs.ago & $0.16(0.07)^{*}$ & $0.68(0.19)$ & $0.93(0.28)$ & $1.12(0.42)$ \\
\hline \multicolumn{5}{|l|}{ COVARIATES } \\
\hline Age & $0.06(0.01)^{* *}$ & $1.08(0.05)$ & $1.18(0.06)^{* * *}$ & $1.05(0.07)$ \\
\hline Wealth & $-0.02(0.02)$ & $0.91(0.06)$ & $0.92(0.07)$ & $0.93(0.10)$ \\
\hline No. of living children & $-0.02(0.01)$ & $0.98(0.04)$ & $1.09(0.05) \dagger$ & $1.00(0.07)$ \\
\hline \multicolumn{5}{|l|}{ Marital status } \\
\hline Married (ref) & 0.00 & 1.00 & 1.00 & 1.00 \\
\hline Never married & $-0.21(0.07)^{* * *}$ & $1.24(0.32)$ & $1.07(0.30)$ & $1.86(0.67) \dagger$ \\
\hline $\begin{array}{l}\text { Divorced/separated/ } \\
\text { widowed }\end{array}$ & $0.28(0.18)$ & $3.44(3.29)$ & $2.43(1.90)$ & $2.09(1.89)$ \\
\hline \multicolumn{5}{|l|}{ Region } \\
\hline Central (ref) & 0.00 & 1.00 & 1.00 & 1.00 \\
\hline South & $0.27(0.07)^{* * *}$ & $3.80(0.98)^{* * *}$ & $1.49(0.40)$ & $1.87(0.61) \dagger$ \\
\hline North & $-0.29(0.09)^{* * *}$ & $1.52(0.43)$ & $0.88(0.28)$ & $0.27(0.13)^{*}$ \\
\hline \multicolumn{5}{|l|}{ Education } \\
\hline None (ref) & 0.00 & 1.00 & 1.00 & 1.00 \\
\hline Primary & $-0.04(0.10)$ & $1.38(0.52)$ & $1.10(0.43)$ & $1.92(1.01)$ \\
\hline$\geq$ secondary & $-0.06(0.12)$ & $1.05(0.44)$ & $0.86(0.39)$ & $1.57(0.96)$ \\
\hline
\end{tabular}

${ }^{*} \mathrm{p} \leq .05 .{ }^{* *} \mathrm{p} \leq .01 .{ }^{* * *} \mathrm{p} \leq .001 .+\mathrm{p} \leq .10$. Results reported as risk differences. §Results reported as odds ratios. Notes: Regressions used in these analyses were Poisson (number of partners) and logistic (remaining risk indicators). ref=reference category. $\mathrm{nr}=$ not reported because of quasi-complete separation of the data.

Next, we examined whether fertility preferences and behaviors differed between orphans and nonorphans (Table 5, page 170, and Table 6, page 171). Female orphans whose mother had died more than five years earlier were far more likely than nonorphans to have ever been married (odds ratio, 5.4). In contrast, men whose father had died in the past five years were less likely than nonorphans to have been married, though this finding was only marginally significant (0.4). Fertility-related outcomes also differed by orphanhood. Both female and male orphans whose mother had died within the past five years desired more children than nonorphans (risk differences, 0.52 and 0.97, respectively). Actual fertility differed as well: Women whose father had died more than five years earlier had had more children than nonorphans (0.31), as had male orphans whose mother had died either in the past five years or more than five years earlier ( 1.06 and 0.47 , respectively).

Finally, the longer-term analysis of orphanhood and fertility also found elevated fertility among orphans (Table 7, page 172). Female orphans who reported in 2006 that their mother had died more than five years earlier had had more children than nonorphans by 2010 (risk difference, 0.99), and male orphans who reported in 2006 than their mother had died in the past five years had had more children than nonorphans by 2010 (1.44). 
TABLE 5. Odds ratios and risk differences (with standard errors) from multivariate regressions examining associations of orphanhood status and selected covariates with fertility-related behaviors among Malawian women aged 15-25

\begin{tabular}{|c|c|c|c|}
\hline Characteristic & $\begin{array}{l}\text { Ever been } \\
\text { married } \neq\end{array}$ & $\begin{array}{l}\text { No.of children } \\
\text { desired§ }\end{array}$ & $\begin{array}{l}\text { No.of children } \\
\text { ever born§ }\end{array}$ \\
\hline \multicolumn{4}{|l|}{ ORPHANHOOD } \\
\hline Alive (ref) & 1.00 & 0.00 & 0.00 \\
\hline Died in past $5 \mathrm{yrs}$. & $0.63(0.55)$ & $0.52(0.24)^{*}$ & $0.13(0.58)$ \\
\hline Died >5 yrs.ago & $5.37(0.03)^{*}$ & $0.15(0.17)$ & $0.26(0.13)$ \\
\hline \multicolumn{4}{|l|}{ Father's status } \\
\hline Alive (ref) & 1.00 & 0.00 & 0.00 \\
\hline Died in past $5 \mathrm{yrs}$. & $1.97(0.31)$ & $0.00(0.14)$ & $-0.21(0.32)$ \\
\hline Died $>5$ yrs.ago & $0.54(0.24)$ & $0.07(0.17)$ & $0.31(0.03)^{*}$ \\
\hline \multicolumn{4}{|l|}{ COVARIATES } \\
\hline Age & $1.55(0.00)^{* * * *}$ & $0.08(0.02)^{* *}$ & $0.28(0.00)^{* * *}$ \\
\hline Wealth & $0.75(0.00)^{* * *}$ & $-0.10(0.03)^{*}$ & $0.02(0.53)$ \\
\hline No. of living children & $13.50(0.00)^{* * *}$ & $0.06(0.03)^{*}$ & na \\
\hline \multicolumn{4}{|l|}{ Marital status } \\
\hline Married (ref) & na & 0.00 & 0.00 \\
\hline Never married & na & $-0.08(0.17)$ & $-0.79(0.00)^{* * *}$ \\
\hline Divorced/separated/widowed & na & $-0.61(0.21)^{*}$ & $-0.11(0.61)$ \\
\hline \multicolumn{4}{|l|}{ Region } \\
\hline Central (ref) & 1.00 & 0.00 & 0.00 \\
\hline South & $0.99(0.97)$ & $0.23(0.13)$ & $0.03(0.79)$ \\
\hline North & $0.40(0.03)^{*}$ & $-0.04(0.14)$ & $-0.09(0.54)$ \\
\hline \multicolumn{4}{|l|}{ Education } \\
\hline None (ref) & 1.00 & 0.00 & 0.00 \\
\hline Primary & $0.35(0.22)$ & $-0.14(0.16)$ & $-0.52(0.00)^{*}$ \\
\hline$\geq$ secondary & $0.21(0.10) \dagger$ & $-0.26(0.22)$ & $-0.87(0.00)^{* * *}$ \\
\hline
\end{tabular}

${ }^{*} \mathrm{p} \leq .05 .{ }^{* *} \mathrm{p} \leq .01 .{ }^{* * *} \mathrm{p} \leq .001 .+\mathrm{p} \leq .10$. $\neq$ Results reported as odds ratios. §Results reported as risk differences. Notes: Sixteen respondents were excluded from analysis of number of children desired because they answered "don't know" or "undetermined" to the relevant survey question. Regressions used in these analyses were logistic (ever been married) and ordinary least squares (remaining outcomes). ref=reference category. na $=$ not applicable. vated rates of pregnancy and STIs (including HIV) among maternal orphans, but not among paternal orphans; $;, 4$ and a third found that risk emerged for paternal orphans only if the father's death had occurred when the child was younger than $12 .{ }^{6}$ Qualitative research is needed to better understand orphans' emotional response to their mother's death, how this response influences their desire to have children, and how social norms and context guide this process.

Studies of fertility, particularly within the context of HIV, often exclude men. However, given that men typically have greater power than women in making marital reproductive decisions, the fertility preferences of male orphans may shift demographic trends far more than those of female orphans. Our findings highlight the possibility that male orphans are reformulating their fertility desires and potentially modifying their reproductive behavior as a result of maternal loss. We did not find an association between orphanhood and worry about HIV, suggesting that fertility desires may be driven by alternative pathways. Future work could shed light on the relationship between orphanhood and fertility by explicitly measuring underlying motivations for elevated fertility desires (e.g., normalcy) and examining whether motivations are similar among both men and women. For example, lineage preservation may be important for men with HIV, whereas women's fertility preferences may be more related to their health. ${ }^{70}$

The importance of a gendered lens is also highlighted by our curious finding that among women, recent orphanhood was associated with pregnancy intentions, but not with realized childbearing. Given that this discrepancy was not present among men, a potential explanation is that women face greater barriers to achieving their desired fertility. Men still dominate contraceptive and fertility decisions, ${ }^{71,72}$ particularly during the early years of a marriage. ${ }^{73}$ Women who want fewer children than their husband does may fear violent reprisals if they use contraceptives, ${ }^{71,74-76}$ those who want more children may be constrained by their partner's stated or assumed preferences. This explanation is consistent with a substantial body of literature on relationship power dynamics and fertility outcomes in Sub-Saharan Africa. ${ }^{77-79}$ An alternative explanation for the discrepancy between desired and actual fertility among recently orphaned women is that in 2006 , women's preferences had changed in response to a parental death, but the women had not yet had time to realize these new preferences. Support for the latter theory comes from the 2010 survey data: By this time, female orphans had had significantly more children than their nonorphaned counterparts had.

The study was conducted in rural Malawi, where women marry and bear children at an early age. This may have influenced the strength of the above findings and may partially explain deviations from past research from neighboring countries. Only one other study has examined pregnancy outcomes among orphans in Malawi; it, too, found no differences between female orphans and nonorphans. ${ }^{7}$ 
Thus, the social desirability of early marriage and early childbearing in Malawi may weaken the impact of orphanhood on related outcomes, particularly among individuals who are no longer adolescents, such as many of the respondents in this study. We encourage further exploration of these hypotheses under different cultural settings.

\section{Limitations}

We note several limitations of the study. The MLSFH has a particularly rich data set, but it was not designed with our study question in mind. The study population was $15-25$ years old at the time of the first interview, and 58\% were already parents. Thus, we cannot distinguish the motivations underlying early pregnancies-those prior to age 15 , which may have the most profound effects on health and education-from later or second pregnancies. Nor can this study speak to total fertility across the reproductive cycle. Studies in Malawi have found that the effect of the HIV epidemic on fertility behavior varies by age, and suggest that the largest impact may be to hasten childbearing rather than to increase the total number of children born. ${ }^{80}$ Our study focused on a youth cohort, and thus data do not allow us to make inferences about net fertility, although our analysis of fertility by 2010 showed that levels continued to be elevated among orphans. We also note that our sample of respondents who had lost a parent within the past five years was relatively small, which may have limited our ability to detect statistical significance in some regression models. Further, the small sample of double orphans, who arguably have experienced the greatest level of trauma, prohibited closer examination of how this group may differ from single orphans. Similarly, we lacked data on respondents' exact age at the time of orphanhood; such data may have provided greater information about whether the magnitude of associations between parental death and fertility outcomes differs by developmental period.

We also note the limitations of using behavioral markers of sexual risk, both because they are subject to social desirability bias and because they often blend complex motivations. For example, the exchange of sex for money may be a purely economic transaction, or it may represent gifts exchanged during courtship. ${ }^{81}$ One of the strengths of this study is our inclusion of a biological marker of risk (HIV status); as with the behavioral variables, we found no association of this measure with orphanhood.

Moreover, while the MLSFH has collected multiple waves of data, many of the key measures were available only in the 2006 wave. As a result, most of our analyses relied on cross-sectional data, which inhibits causal interpretation. We note, however, that an advantage of our study is that in many cases we were able to establish the probable order of events for our key variables. In particular, we were able to identify respondents whose parents had died five or more years before the 2006 wave of the MLSFH; it is unlikely that fertility preferences of these respondents developed prior to parental death. However, determining the order of events is more challenging for individuals
TABLE 6. Odds ratios and risk differences (with standard errors) from multivariate regressions examining associations of orphanhood status and selected covariates with fertility-related behaviors among Malawian men aged 15-25

\begin{tabular}{|c|c|c|c|}
\hline Characteristic & $\begin{array}{l}\text { Ever been } \\
\text { married } \neq\end{array}$ & $\begin{array}{l}\text { No.of children } \\
\text { desired§ }\end{array}$ & $\begin{array}{l}\text { No.of children } \\
\text { ever born§ }\end{array}$ \\
\hline \multicolumn{4}{|l|}{ ORPHANHOOD } \\
\hline \multicolumn{4}{|l|}{ Mother's status } \\
\hline Alive (ref) & 1.00 & 0.00 & 0.00 \\
\hline Died in past $5 \mathrm{yrs}$. & $2.23(1.66)$ & $0.97(0.43)^{*}$ & $1.06(0.31)^{* * *}$ \\
\hline Died $>5$ yrs.ago & $1.08(0.48)$ & $0.03(0.24)$ & $0.47(0.17)^{* * *}$ \\
\hline \multicolumn{4}{|l|}{ Father's status } \\
\hline Alive (ref) & 1.00 & 0.00 & 0.00 \\
\hline Died in past $5 \mathrm{yrs}$. & $0.44(0.21) \dagger$ & $0.17(0.26)$ & $0.08(0.19)$ \\
\hline Died $>5$ yrs.ago & $1.50(0.50)$ & $0.00(0.19)$ & $0.01(0.14)$ \\
\hline \multicolumn{4}{|l|}{ COVARIATES } \\
\hline Age & $1.69(0.11)^{* * *}$ & $-0.06(0.03) \dagger$ & $0.03(0.02)$ \\
\hline Wealth & $0.78(0.08)^{*}$ & $-0.06(0.04)$ & $0.02(0.03)$ \\
\hline No. of living children & $2.24(0.38)^{* * *}$ & $0.10(0.03)^{* *}$ & na \\
\hline \multicolumn{4}{|l|}{ Marital status } \\
\hline Married (ref) & na & 0.00 & 0.00 \\
\hline Never married & na & $-0.19(0.18)$ & $-1.27(0.12)^{* * *}$ \\
\hline Divorced/separated/widowed & na & $0.06(0.57)$ & $0.30(0.39)$ \\
\hline \multicolumn{4}{|l|}{ Region } \\
\hline Central (ref) & 1.00 & 0.00 & 0.00 \\
\hline South & $2.61(0.84)^{* * *}$ & $0.12(0.18)$ & $0.26(0.13)^{*}$ \\
\hline North & $0.57(0.20)$ & $0.25(0.20)$ & $0.15(0.14)$ \\
\hline \multicolumn{4}{|l|}{ Education } \\
\hline None (ref) & 1.00 & 0.00 & 0.00 \\
\hline Primary & $2.25(1.04) \dagger$ & $-0.42(0.28)$ & $-0.66(0.18)^{* * *}$ \\
\hline zsecondary & $1.79(0.94)$ & $-0.59(0.31) \dagger$ & $-0.82(0.21)^{* * *}$ \\
\hline
\end{tabular}

${ }^{*} \mathrm{p} \leq .05 .{ }^{* *} \mathrm{p} \leq .01 .{ }^{* * *} \mathrm{p} \leq .001 .+\mathrm{p} \leq .10$. \#Results reported as odds ratios. §Results reported as risk differences. Notes: Eighteen respondents were excluded from analysis of number of children desired because they answered "don't know" or "undetermined" to the relevant survey question. Regressions used in these analyses were logistic (ever been married) and ordinary least squares (remaining outcomes). ref=reference category. na=not applicable.

whose parents had died within the past five years. Moreover, unmeasured factors may have contributed to both orphanhood and elevated desired fertility. This study has generated a compelling hypothesis; studies designed to explicitly evaluate this hypothesis are necessary to provide more rigorous support. We note that HIV and fertility are linked through behavior, and that the pathways explored in this study are thus not necessarily mutually exclusive. Future studies should continue to jointly examine both outcomes to highlight any potential interplay.

Finally, a potential limitation of any study involving panel data is attrition bias. ${ }^{82}$ To explore this issue, we examined whether respondents who were interviewed in 2006 were different from those who departed from the sample between that wave and the previous one (2004). We found small but statistically significant differences in several measures: Compared with respondents who were reinterviewed in 2006, those who were not reinterviewed were wealthier, better educated and more likely to be married (Appendix Table 1, page 172). The two groups had similar levels of maternal orphanhood, but individuals who were not reinterviewed were less likely than those who were to have a living father. From these results, we conclude that while some attrition bias was present in this research, the 
TABLE 7. Risk differences (with standard errors) from multivariate ordinary least squares regressions examining associations of orphanhood status and selected covariates in 2006 with number of children ever born in 2010 among Malawian young adults aged $15-25$, by sex

Characteristic

Women

Men

ORPHANHOOD

Mother's status

Alive (ref)

Died in past $5 \mathrm{yrs}$.

Died $>5$ yrs.ago

0.00 0.00

Father's status

Alive (ref)

Died in past $5 \mathrm{yrs}$.

Died $>5$ yrs.ago

$0.36(0.42)$

$1.44(0.43)^{* * *}$

$0.99(0.30)^{*}$

$0.23(0.25)$

COVARIATES

Age

Wealth

$\begin{array}{ll}0.00 & 0.00\end{array}$

$-0.32(0.35) \quad-0.06(0.29)$

$0.27(0.24) \quad-0.07(0.20)$

\section{Marital status}

Married (ref)

Never married

Divorced/separated/widowed

$0.21(0.04)^{* * *} \quad 0.04(0.03)$

$0.01(0.07)$

$0.00 \quad 0.00$

$-1.02(0.30)^{* * *}-1.82(0.18)^{* * *}$

$-0.97(0.39)^{*} \quad-1.46(0.66)^{*}$

Region

Central (ref)

South

North

0.00

$0.44(0.22)+$

0.00

$0.17(0.25)$

$0.44(0.19) *$

Education

None (ref)

Primary

$\geq$ secondary

$\begin{array}{ll}0.00 & 0.00 \\ -0.74(0.26)^{* * *} & -1.13(0.30)^{* * *}\end{array}$

$-1.28(0.39)^{* * *}-1.08(0.33)^{* * *}$

${ }^{*} \mathrm{p} \leq .05 .{ }^{* * *} \mathrm{p} \leq .001 .+\mathrm{p} \leq .10$. Notes: Sample consisted of 374 women and

288 men. ref=reference category.

effect is likely not substantial, as the differences between groups in social and demographic characteristics were small in magnitude and the differences in orphanhood were limited.

\section{Policy Relevance}

While we acknowledge that our findings were obtained in a country with high fertility and a generalized HIV epidemic, we believe that they have relevance for programmers trying to reduce sexual risk among orphans throughout the region. First, our results suggest that structural interventions will fall short of fully addressing early childbearing and associated HIV risk among orphans. We are not suggesting that such interventions are not needed more generally-cash transfers, for example, are an increasingly popular structural intervention with demonstrated impact on sexual behaviors among adolescents ${ }^{83}$-but rather that their utility is in targeting more universal disadvantage. Our research suggests that orphans may have additional issues that contribute to their fertility risk, and that programs should consider offering counseling to help orphans understand their grief and develop healthy coping mechanisms in response to uncertainty. We are not the first to suggest that improving coping skills may be one means to reduce risk, or to find evidence supporting the idea; in a U.S. study, a family coping intervention reduced rates of early pregnancy among daughters of HIV-positive parents. ${ }^{37}$ However, the authors cautioned that the intervention was not sufficient to mitigate risk among youth with extreme emotional distress. For this group, we suggest that psychological interventions, such as those focused on depression, ${ }^{84}$ may be necessary. Such interventions, delivered in tandem with structural interventions, may help orphans begin to conceptualize a more positive future independent of childbearing.

Second, HIV and pregnancy prevention programs that treat unprotected sex solely as an adverse outcome may alienate youth who want to start a family. For example, many HIV prevention interventions focus on delaying sexual activity and promoting contraceptive use; the underlying assumption is that adolescents are already motivated to avoid pregnancy. However, our findings are consistent with research that has questioned the utility of this approach in isolation. For example, McQueston and colleagues suggested that contraceptive knowledge and access are not the primary determinants of adolescent fertility, and that interventions should be redirected toward underlying causes of fertility, including fertility preferences. ${ }^{85}$ Thus, we recommend that programs incorporate two additional components. First, they should directly address fertility preferences through interventions such

APPENDIX TABLE 1. Selected characteristics in 2004 of Malawian young adults aged 15-25 who were interviewed in both 2004 and 2006 and those who were interviewed only in 2004

Characteristic

Interviewed Interviewed in both years only in 2004 $(\mathrm{N}=751) \quad(\mathrm{N}=409)$

SOCIAL AND DEMOGRAPHIC

Mean age

19.6

19.5

Mean normalized wealth index score $-0.07^{*} \quad 0.20$

Marital status

Married

Never married

Divorced/separated/widowed

$49.5^{*} \quad 55.7$

$49.1^{*} \quad 42.1$

Region

Central

South

North

$\begin{array}{ll}31.8 & 27.3\end{array}$

$34.3 \quad 33.3$

Education

None

Primary

zsecondary

$\begin{array}{ll}34.3 & 33.3 \\ 33.9^{*} & 39.5\end{array}$

Mother is alive

Father is alive

$6.3 \quad 5.6$

$74.4^{*} \quad 68.1$

$19.4^{* *} \quad 26.3$

RISK INDICATORS

Mean no. of partners

$86.2 \quad 82.5$

Ever exchanged sex for money
Has had extramarital partner

Has had extram

Worried about HIV

$76.0^{*}$

82.5
69.2

FERTILITY OUTCOMES

Mean no. of children ever born

Mean no. of living children

$\begin{array}{rr}2.57 & 2.31 \\ 36.5 & 40.5 \\ 8.4 & 6.8 \\ 2.4 & 4.6 \\ 38.8 & 39.5\end{array}$

${ }^{*} \mathrm{p} \leq .05 .{ }^{* *} \mathrm{p} \leq .01$. Notes: All values are percentages unless otherwise indicated. Percentages may not total 100.0 because of rounding. 
as those described above. Second, they should explicitly recognize that many youth, orphaned and otherwise, desire children. Thus, information must be available on how to have children safely in the context of a generalized HIV epidemic-and must be provided to young men as well as young women.

\section{Conclusion}

The study findings suggest that orphanhood is not associated with sexual risk-taking in a cohort of Malawian youth, but is positively associated with fertility desires and childbearing. These associations were observed, however, only among specific subpopulations of orphans, and male maternal orphans were the only group to demonstrate elevations in both fertility desires and actual childbearing. Programs intended to reduce HIV risk behaviors and early pregnancy among orphaned youth in Malawi need to acknowledge and address personal desires for parenthood as part of a multipronged approach.

\section{REFERENCES}

1. Heymann S, Sherr L and Kidman R, eds., Protecting Childhood in the AIDS Pandemic: Finding Solutions that Work, New York: Oxford University Press, 2012.

2. World Health Organization (WHO), Adolescent Pregnancy-Unmet Needs and Undone Deeds: A Review of the Literature and Programmes, Geneva: WHO, 2007.

3. Gregson S et al., HIV infection and reproductive health in teenage women orphaned and made vulnerable by AIDS in Zimbabwe, AIDS Care, 2005, 17(7):785-794

4. Kang M et al., Maternal versus paternal orphans and HIV/STI risk among adolescent girls in Zimbabwe, AIDS Care, 2008, 20(2):214-217.

5. Operario D et al., Prevalence of parental death among young people in South Africa and risk for HIV infection, Journal of Acquired Immune Deficiency Syndromes, 2007, 44(1):93-98.

6. Birdthistle IJ et al., From affected to infected? Orphanhood and HIV risk among female adolescents in urban Zimbabwe, AIDS, 2008, 22(6):759-766.

7. Palermo $\mathrm{T}$ and Peterman A, Are female orphans at risk for early marriage, early sexual debut, and teen pregnancy? Evidence from SubSaharan Africa, Studies in Family Planning, 2009, 40(2):101-112.

8. Nyirenda M, McGrath N and Newell M-L, Gender differentials in the impact of parental death: adolescent's sexual behaviour and risk of HIV infection in rural South Africa, Vulnerable Children and Youth Studies, 2010, 5(3):284-296.

9. Guo Y, Li X and Sherr L, The impact of HIV/AIDS on children's educational outcome: a critical review of global literature, AIDS Care, 2012, 24(8):993-1012.

10. Case A and Ardington C, The impact of parental death on school outcomes: longitudinal evidence from South Africa, Demography, 2006, 43(3):401-420.

11. Evans DK and Miguel E, Orphans and schooling in Africa: a longitudinal analysis, Demography, 2007, 44(1):35-57.

12. Kürzinger ML et al., Education status among orphans and nonorphans in communities affected by AIDS in Tanzania and Burkina Faso, AIDS Care, 2008, 20(6):726-732.

13. Sharma M, Orphanhood and schooling outcomes in Malawi, American Journal of Agricultural Economics, 2006, 88(5):1273-1278.

14. Bicego G, Rutstein S and Johnson K, Dimensions of the emerging orphan crisis in Sub-Saharan Africa, Social Science \& Medicine, 2003, 56(6):1235-1247.

15. Ainsworth M and Filmer D, Inequalities in children's schooling:
AIDS, orphanhood, poverty, and gender, World Development, 2006 34(6):1099-1128.

16. Cluver L et al., Transactional sex amongst AIDS-orphaned and AIDS-affected adolescents predicted by abuse and extreme poverty, Journal of Acquired Immune Deficiency Syndromes, 2011, 58(3):336-343.

17. Nyamukapa CA et al., HIV-associated orphanhood and children's psychosocial distress: theoretical framework tested with data from Zimbabwe, American Journal of Public Health, 2008, 98(1):133-141.

18. Juma M et al., Risky sexual behavior among orphan and nonorphan adolescents in Nyanza Province, Western Kenya, AIDS and Behavior, 2013, 17(3):951-960.

19. Chae S, Timing of orphanhood, early sexual debut, and early marriage in four Sub-Saharan African countries, Studies in Family Planning, 2013, 44(2):123-146.

20. Mkandawire P, Tenkorang E and Luginaah IN, Orphan status and time to first sex among adolescents in northern Malawi, AIDS and Behavior, 2013, 17(3):939-950

21. Baird S et al., The short-term impacts of a schooling conditional cash transfer program on the sexual behavior of young women, Health Economics, 2010, 19(Suppl. 1):55-68

22. Cho H et al., Keeping adolescent orphans in school to prevent human immunodeficiency virus infection: evidence from a randomized controlled trial in Kenya, Journal of Adolescent Health, 2011, 48(5):523526 .

23. Birdthistle I et al., Is education the link between orphanhood and HIV/HSV-2 risk among female adolescents in urban Zimbabwe? Social Science E Medicine, 2009, 68(10):1810-1818.

24. WHO, Making Pregnancy Safer, Geneva: WHO, 2008.

25. Dyer SJ, The value of children in African countries: insights from studies on infertility, Journal of Psychosomatic Obstetrics and Gynaecology, 2007, 28(2):69-77.

26. Hollos M and Larsen U, Motherhood in Sub-Saharan Africa: the social consequences of infertility in an urban population in northern Tanzania, Culture, Health E Sexuality, 2008, 10(2):159-173.

27. van Balen $\mathrm{F}$ and Bos $\mathrm{H}$, The social and cultural consequences of being childless in poor-resource areas, Facts, Views $\&$ Vision in ObGyn, 2009, 1(2):106-121.

28. Nzioka C, Perspectives of adolescent boys on the risks of unwanted pregnancy and sexually transmitted infections: Kenya, Reproductive Health Matters, 2001, 9(17):108-117.

29. Barker G and Ricardo C, Young Men and the Construction of Masculinity in Sub-Saharan Africa: Implications for HIV/AIDS, Conflict, and Violence, Washington, DC: World Bank, 2005.

30. Rosengard C et al., Adolescent pregnancy intentions and pregnancy outcomes: a longitudinal examination, Journal of Adolescent Health, 2004, 35(6):453-461.

31. Jaccard J, Dodge T and Dittus P, Do adolescents want to avoid pregnancy? Attitudes toward pregnancy as predictors of pregnancy, Journal of Adolescent Health, 2003, 33(2):79-83.

32. Rubin V and East PL, Adolescents' pregnancy intentions: relations to life situations and caretaking behaviors prenatally and 2 years postpartum, Journal of Adolescent Health, 1999, 24(5):313-320.

33. Davies SL et al., Pregnancy desire among disadvantaged African American adolescent females, American Journal of Health Behavior 2003, 27(1):55-62.

34. Ravert AA and Martin J, Family stress, perception of pregnancy, and age of first menarche among pregnant adolescents, Adolescence, 1997, 32(126):261-269.

35. Geronimus AT, Teenage childbearing and social and reproductive disadvantage: the evolution of complex questions and the demise of simple answers, Family Relations, 1991, 40(4):463-471.

36. Afable-Munsuz A et al., A positive orientation toward early motherhood is associated with unintended pregnancy among New Orleans youth, Maternal and Child Health Journal, 2006, 10(3):265-276.

37. Sipsma HL et al., Adolescent pregnancy desire and pregnancy inci- 
dence, Women's Health Issues, 2011, 21(2):110-116.

38. Iacovou M and Tavares LP, Yearning, learning, and conceding: reasons men and women change their childbearing intentions, Population and Development Review, 2011, 37(1):89-123.

39. Heiland F, Prskawetz A and Sanderson WC, Are individuals' desired family sizes stable? Evidence from West German panel data, European Journal of Population, 2008, 24(2):129-156.

40. Liefbroer AC, Changes in family size intentions across young adulthood: a life-course perspective, European Journal of Population, 2009, 25(4):363-386.

41. Sennott $C$ and Yeatman S, Stability and change in fertility preferences among young women in Malawi, International Perspectives on Sexual and Reproductive Health, 2012, 38(1):34-42.

42. Kodzi IA, Casterline JB and Aglobitse P, The time dynamics of individual fertility preferences among rural Ghanaian women, Studies in Family Planning, 2010, 4l(1):45-54

43. Yeatman S, Sennott C and Culpepper S, Young women's dynamic family size preferences in the context of transitioning fertility, Demography, 2013, 50(5):1715-1737.

44. Atwine B, Cantor-Graae E and Bajunirwe F, Psychological distress among AIDS orphans in rural Uganda, Social Science \& Medicine, 2005, 6l(3):555-564

45. Cluver L and Gardner F, The mental health of children orphaned by AIDS: a review of international and southern African research, Journal of Child and Adolescent Mental Health, 2007, 19(1):1-17.

46. Ford K and Hosegood V, AIDS mortality and the mobility of children in KwaZulu Natal, South Africa, Demography, 2005, 42(4):757768

47. Hosegood $\mathrm{V}$ et al., The impact of adult mortality on household dissolution and migration in rural South Africa, AIDS, 2004, 18(11):1585-1590

48. Nyamukapa CA et al., Causes and consequences of psychological distress among orphans in eastern Zimbabwe, AIDS Care, 2010, 22(8):988-996

49. Cluver L, Gardner F and Operario D, Effects of stigma on the mental health of adolescents orphaned by AIDS, Journal of Adolescent Health, 2008, 42(4):410-417.

50. Cooper D et al., "Life is still going on": reproductive intentions among HIV-positive women and men in South Africa, Social Science E Medicine, 2007, 65(2):274-283.

51. Montgomery KS, Planned adolescent pregnancy: what they wanted, Journal of Pediatric Health Care, 2002, 16(6):282-289.

52. Berglund $S$ et al., The background of adolescent pregnancies in Nicaragua: a qualitative approach, Social Science \& Medicine, 1997. 44(1):1-12.

53. Clark S, Kabiru C and Mathur R, Relationship transitions among youth in urban Kenya, Journal of Marriage and Family, 2010, 72(1):7388

54. Mojola SA, Multiple transitions and HIV risk among orphaned Kenyan schoolgirls, Studies in Family Planning, 2011, 42(1):29-40.

55. Hayford SR, Agadjanian V and Luz L, Now or never: perceived HIV status and fertility intentions in rural Mozambique, Studies in Family Planning, 2012, 43(3):191-199.

56. Trinitapoli J and Yeatman S, Uncertainty and fertility in a generalized AIDS epidemic, American Sociological Review, 2011, 76(6):935954

57. Sherr L and Barry N, Fatherhood and HIV-positive heterosexual men, HIV Medicine, 2004, 5(4):258-263.

58. Yeatman SE, The impact of HIV status and perceived status on fertility desires in rural Malawi, AIDS and Behavior, 2009, 13(Suppl. 1):12-19.

59. Operario D et al., HIV infection and sexual risk behaviour among youth who have experienced orphanhood: systematic review and meta-analysis, Journal of the International AIDS Society, 2011, 14(25):1-11.

60. Malawi National Statistical Office (NSO) and ICF Macro, Malawi
Demographic and Health Survey 2010, Zomba, Malawi: NSO; and Calverton, MD, USA: ICF Macro, 2011.

61. Malik K et al., Human Development Report 2013. The Rise Of the South: Human Progress in a Diverse World, New York: United Nations Development Programme, 2013.

62. United Nations Children's Fund (UNICEF), Malawi Annual Report 2010, Lilongwe, Malawi: UNICEF Malawi Country Office, 2011.

63. NSO and ICF Macro, Malawi Demographic and Health Survey 2004 Zomba, Malawi: NSO; and Calverton, MD, USA: ICF Macro, 2005.

64. Reniers G, Divorce and remarriage in rural Malawi, Demographic Research, 2003, Special collection 1, Art. 6, <http://www.demographicresearch.org/special/1/6/sl-6.pdf>, accessed Nov. 12, 2014.

65. Boileau $C$ et al., Sexual and marital trajectories and HIV infection among ever-married women in rural Malawi, Sexually Transmitted Infections, 2009, 85(Suppl. 1):i27-i33.

66. Anglewicz P et al., The Malawi Diffusion and Ideational Change Project 2004-06: data collection, data quality, and analysis of attrition, Demographic Research, 2009, 20(21):503-540.

67. Watkins $S$ et al., Introduction to "Research on Demographic Aspects of HIV/AIDS in Rural Africa," Demographic Research, 2003 Special collection 1, Art. 1, <http://www.demographic-research.org/ special/1/1/sl-1.pdf>, accessed Nov. 12, 2014.

68. Bignami-Van Assche S, Reniers G and Weinreb AA, An assessment of the KDICP and MDICP data quality: interviewer effects, question reliability and sample attrition, Demographic Research, 2003 Special collection 1, Art. 2, <http://wllww.demographic-research.org/ special/1/2/sl-2.pdf>, accessed Nov. 12, 2014.

69. Filmer D and Pritchett LH, Estimating wealth effects without expenditure data-or tears: an application to educational enrollments in states of India, Demography, 2001, 38(1):115-132

70. Nattabi B et al., A systematic review of factors influencing fertility desires and intentions among people living with HIV/AIDS: implications for policy and service delivery, AIDS and Behavior, 2009, 13(5):949-968

71. Ezeh AC, The influence of spouses over each other's contraceptive attitudes in Ghana, Studies in Family Planning, 1993, 24(3):163-174.

72. DeRose LF, Dodoo FN and Patil V, Fertility desires and perceptions of power in reproductive conflict in Ghana, Gender \& Society, 2002 16(1):53-73.

73. Bankole A, Desired fertility and fertility behaviour among the Yoruba of Nigeria: a study of couple preferences and subsequent fertility, Population Studies, 1995, 49(2):317-328

74. Bawah AA et al., Women's fears and men's anxieties: the impact of family planning on gender relations in northern Ghana, Studies in Family Planning, 1999, 30(1):54-66.

75. Fort AL, Investigating the social context of fertility and family planning: a qualitative study in Peru, International Family Planning Perspectives, 1989, 15(3):88-95.

76. Heise L, Ellsberg M and Gottmoeller M, A global overview of gender-based violence, International Journal of Gynecology \& Obstetrics, 2002, 78(Suppl. 1):S5-S14.

77. Blanc AK, The effect of power in sexual relationships on sexual and reproductive health: an examination of the evidence, Studies in Family Planning, 2001, 32(3):189-213

78. Varga CA, How gender roles influence sexual and reproductive health among South African adolescents, Studies in Family Planning, 2003, 34(3): 160-172.

79. Stephenson R, Bartel D and Rubardt M, Constructs of power and equity and their association with contraceptive use among men and women in rural Ethiopia and Kenya, Global Public Health, 2012 7(6):618-634

80. Durevall D and Lindskog A, Uncovering the impact of the HIV epidemic on fertility in Sub-Saharan Africa: the case of Malawi, Journal of Population Economics, 2011, 24(2):629-655.

81. Poulin M, Sex, money, and premarital partnerships in southern Malawi, Social Science \& Medicine, 2007, 65(11):2383-2393. 
82. Anglewicz P, Migration, marital change, and HIV infection in Malawi, Demography, 2012, 49(1):239-265.

83. Pettifor A et al., Can money prevent the spread of HIV? A review of cash payments for HIV prevention, AIDS and Behavior, 2012, 16(7):1729-1738.

84. Bolton $\mathrm{P}$ et al., Interventions for depression symptoms among adolescent survivors of war and displacement in northern Uganda: a randomized controlled trial, Journal of the American Medical Association, 2007, 298(5):519-527.

85. McQueston K, Silverman R and Glassman A, Adolescent fertility in low-and middle-income countries: effects and solutions, CGD Working Paper, Washington, DC: Center for Global Development, 2012, No. 295.

\section{RESUMEN}

Contexto: Aunque una importante cantidad de bibliografía sugiere que las personas huérfanas padecen situaciones de desventaja en relación con sus pares no huérfanos, la naturaleza de esta desventaja y el mecanismo que la propicia no son del todo comprendidos. Hay evidencia que sugiere que las personas huérfanas experimentan una fecundidad elevada, quizás debido a que las desventajas estructurales les conducen a tomar riesgos sexuales. Una explicación alternativa es que las personas huérfanas quedan embarazadas intencionalmente para lograr un sentido de normalidad, aceptación y amor.

Métodos: Se usaron datos de la ola de 2006 del Estudio Longitudinal de Familias y Salud de Malaui sobre 1,033 adultos jóvenes de entre 15 a 25 años de edad, para examinar la relación de la orfandad materna y paterna con los indicadores de riesgo sexual, y la fecundidad deseada y real. Se utilizaron análisis de regresión para ajustar por covariables, incluyendo las características sociales y demográficas y el tiempo transcurrido desde la muerte de los padres.

Resultados: Veintiséis por ciento de las personas entrevistadas habia perdido a su padre y $15 \%$ a su madre. La orfandad no estuvo asociada con la toma de riesgos sexuales. Sin embargo, las personas cuya madre había muerto en los últimos cinco años deseaban más hijos que aquellas cuya madre todavía vivía (diferencias de riesgo de 0.52 en mujeres y 0.97 en hombres). La fecundidad real fue elevada entre las mujeres cuyo padre había muerto hace más de cinco años (0.31) y entre los hombres cuya madre había muerto en los últimos cinco años (1.06) o más de cinco años antes (0.47).

Conclusión: Los aumentos en la fecundidad deseada y real entre las personas huérfanas son consistentes con la hipótesis de que dichas personas quedan embarazadas intencionalmente. Es posible que las estrategias que abordan los deseos per- sonales de paternidad deban ser parte de los programas de prevención dirigidos a las y los jóvenes huérfanos.

\section{RÉSUMÉ}

Contexte: Si la documentation laisse souvent entendre que les orphelins sont désavantagés par rapport à leurs pairs qui ne sont pas orphelins, la nature du désavantage et les mécanismes qui l'entraînent ne sont pas bien compris. Certaines données donnent à penser que les orphelins présentent une fécondité élevée, sous l'effet peut-être d'un désavantage structurel qui les conduit à prendre plus de risques sexuels. Une autre explication serait qu'ils recherchent intentionnellement les grossesses pour retrouver un sens de normalité, d'acceptation et d'amour.

Méthodes: Les données relatives à 1033 jeunes adultes âgés de 15 à 25 ans, extraites de la vague 2006 de l'Étude longitudinale des familles et de la santé au Malawi, ont été utilisés pour examiner la relation du fait d'être orphelin de mère et de père avec les indicateurs de risque sexuel et la fécondité désirée et effective. L'examen a procédé par analyses de régression avec correction des covariables de caractéristiques sociodémographiques et temps écoulé depuis la mort du parent.

Résultats: Vingt-six pour cent des répondants avaient perdu leur père et $15 \%$, leur mère. Le fait d'être orphelin ne s'est pas révélé associé à la prise de risques sexuels. En revanche, les répondants dont la mère était décédée durant les cinq dernières années désiraient plus d'enfants que ceux dont la mère était toujours en vie (excès de risque de 0,52 côté femmes et 0,97 côté hommes). La fécondité effective est élevée chez les femmes dont le père était décédé plus de cinq ans plus tôt $(0,31)$ et chez les hommes dont la mère l'était durant les cinq dernières années $(1,06)$ ou plus de cinq ans plus tôt $(0,47)$.

Conclusion: L'élévation de la fécondité désirée et effective parmi les orphelins s'aligne sur l'hypothèse que les orphelins recherchent intentionnellement leurs grossesses. Il serait peutêtre utile d'intégrer des stratégies relatives aux désirs personnels d'être parents dans les programmes de prévention destinés à la jeunesse orpheline.

\section{Acknowledgments}

The Malawi Longitudinal Study of Families and Health has been funded by grants R01HD053781, R01HD044228 and R01HD/ MH41713 from the National Institute of Child Health and Development.

Author contact: rachel.kidman@stonybrook.edu 